\title{
A new enigmatic lineage of Dascillidae (Coleoptera: Elateriformia) from Eocene Baltic amber described using X-ray microtomography, with notes on Karumiinae morphology and classification
}

\author{
Robin Kundrata ${ }^{1}$, Matthew L. Gimmel ${ }^{2}$, Gabriela Packova ${ }^{1}$, Andris Bukejs ${ }^{3}$, and Stephan M. Blank ${ }^{4}$ \\ ${ }^{1}$ Department of Zoology, Faculty of Science, Palacky University, 17. listopadu 50, Olomouc, 77146, Czech Republic \\ ${ }^{2}$ Santa Barbara Museum of Natural History, 2559 Puesta del Sol Rd, Santa Barbara, CA 93105-2998, USA \\ ${ }^{3}$ Institute of Life Sciences and Technologies, Daugavpils University, Vienības 13, Daugavpils, 5401, Latvia \\ ${ }^{4}$ Senckenberg Deutsches Entomologisches Institut, Eberswalder Strasse 90, 15374 Müncheberg, Germany
}

Correspondence: Robin Kundrata (robin.kundrata@upol.cz)

Received: 13 March 2021 - Revised: 17 April 2021 - Accepted: 20 April 2021 - Published: 21 May 2021

\begin{abstract}
Dascillidae are a species-poor beetle group with a scarce fossil record. Here, we describe Baltodascillus serraticornis gen. et sp. nov. based on a well-preserved specimen from Eocene Baltic amber. It differs from all known Dascillidae by its reduced mandibles. After studying the specimen using light microscopy and X-ray microtomography, we tentatively place this genus in the poorly defined subfamily Karumiinae based on the large eyes, serrate antennae, and lack of prosternal process. This is the first representative of the Dascillidae formally described from Baltic amber and the first described fossil member of the subfamily Karumiinae. We briefly discuss the problematic higher classification of Dascillidae, along with the morphology and biogeography of the group.
\end{abstract}

\section{Introduction}

Dascillidae are a small beetle family with about 100 extant species classified in 11 genera distributed in all zoogeographic realms (Ivie and Barclay, 2011; Jin et al., 2013b; Lawrence, 2016; Johnston and Gimmel, 2020). Together with the still-smaller family Rhipiceridae, they form the superfamily Dascilloidea within the series Elateriformia (Lawrence, 2016; Kundrata et al., 2017). Dascillidae are further divided into two subfamilies with unclear limits, i.e., Dascillinae (six genera, about 80 species) and Karumiinae (five genera, about 20 species) (Lawrence and Newton, 1995; Ivie and Barclay, 2011; Lawrence, 2016). There has been no worldwide taxonomic revision of Dascillidae. However, the subfamily Dascillinae has received particular attention during the last decade. The worldwide genera and Asian species of Dascillinae were revised by Jin et al. (2013b), with additional species described in several subsequent papers (Jin et al., 2015, 2016, 2017; Li et al., 2017; Fang et al., 2020; Wang et al., 2020a, b). The only Australian genus of the family, Notodascillus Carter, 1935, was revised by Jin et al. (2013a), and Terzani et al. (2017) revised the Western Palearctic species of Dascillus Latreille, 1797. Most recently, Johnston and Gimmel (2020) reviewed the North American Dascillidae of both subfamilies and also provided a species checklist for the New World. Although Karumiinae were included in the latter study, issues of higher classification did not receive much attention. Ivie and Barclay (2011) revised the status of certain genera associated with Karumia Escalera, 1913, but a comprehensive revision of Karumiinae in the modern sense is missing.

The fossil record of Dascillidae is rather scarce and was critically reviewed by Jin et al. (2013c). Two Australian Upper Triassic genera, Apheloodes Dunstan, 1923 and Leioodes Dunstan, 1923, described based on a single elytron each, were removed from Dascillidae and placed in Coleoptera incertae sedis, and the North American Miocene Protacnaeus Wickham, 1914 and Miocyphon Wickham, 1914 were transferred to Psephenidae and Scirtidae, respectively. The monotypic genus Mesodascilla Martynov, 1926 from the Jurassic Karatau locality in Kazakhstan, which was originally assigned to Dascillidae (Martynov, 1926), has been re- 
cently treated either as a member of Eulichadidae (Kirejtshuk and Azar, 2013) or Lasiosynidae (Yan et al., 2014). Jin et al. (2013c) kept only three genera which contain fossil species in Dascillidae. The genus Lyprodascillus Zhang, 1989, with two described species from the Miocene of China, has remained tentatively in Dascillidae, although authors could not confirm its systematic placement based on the available descriptions and illustrations (Jin et al., 2013c). The only Mesozoic dascillid genus is the monotypic Cretodascillus Jin, Slipinski, Pang \& Ren, 2013 from the Cretaceous Yixian Formation in China (Jin et al., 2013c). Most fossil species are classified in the extant genus Dascillus, which currently contains six species from the Miocene Shandong Formation of China (Zhang, 1989; Zhang et al., 1994), one from the Miocene Latah Formation of the USA (Lewis, 1973), and one from the Eocene Florissant Formation of the USA (Wickham, 1911). However, at least some of these species probably do not belong to Dascillidae and are kept there only tentatively until the type material is examined in detail (Jin et al., 2013c). Some fossil taxa attributed to Dascillidae, and usually to Dascillus (sometimes as its synonym Atopa Paykull, 1799), remain unnamed, as for example the specimens found in the Oligocene Aix-en-Provence in southern France (Hope, 1847) or specimens reported from Baltic amber (Helm, 1886, 1896; Klebs, 1910; Larsson, 1978; Spahr, 1981).

In this study, we describe an enigmatic new genus based on a well-preserved specimen from Eocene Baltic amber. This is the first described representative of Dascillidae from amber. We discuss its systematic placement as well as the higher classification and biogeography of Dascillidae.

\section{Material and methods}

The amber piece was polished by hand, allowing improved views of the included specimen, and was not subjected to any additional treatment. For the purpose of light microscopic image capture, the amber specimen was fixed at a suitable angle of view to a Petri dish with gray plasticine modeling clay (Pelikan, Germany, model number 601492). It was photographed submersed in glycerol to prevent reflections and to reduce visibility of small scratches on the surface of the amber piece. Images were taken with a Leica MC 190 HD camera attached to a motorized Leica M205 C stereo microscope equipped with the flexible dome Leica LED5000 HDI or the conventional ring light Leica LED5000 RL-80/40 as an illuminator, applying the software Leica Application Suite X (version 3.7.2.22383, Leica Microsystems, Switzerland). Stacks of photographs were combined with the software Helicon Focus Pro (version 7.6.4, Kharkiv, Ukraine), applying the rendering method "depth map" or "weighted average".

The X-ray micro-CT ( $\mu \mathrm{CT})$ observations were conducted at Daugavpils University, Daugavpils, Latvia (DU), using a Zeiss Xradia 510 Versa system. In order to achieve the best results possible, three scans were conducted: habitus, head/prothorax and abdomen. For prothorax/head and abdomen scans, the parameters were mostly identical with the exception of exposure time. For both scans, sample-detector and source-sample distances were set to 37.4 and $38 \mathrm{~mm}$, respectively, the source X-ray beam energy was set to $30 \mathrm{kV}$ and power of $2 \mathrm{~W}$. Tomographic slices were generated from 2401 slices through 360-degree rotation, using $4 \times$ objective. Achieved voxel size during scan was $3.3 \mu \mathrm{m}$. Exposure times were set to $8 \mathrm{~s}$ for the abdomen scan and $9 \mathrm{~s}$ for the head/prothorax scan. The overall scan was carried out at Xray beam energy of $40 \mathrm{kV}$ and power of $3 \mathrm{~W}$, source-sample distance was set to $24.4 \mathrm{~mm}$ and sample-detector distance was set to $117.7 \mathrm{~mm}$. Tomographic slices were generated from 1601 slices through 360 -degree rotation using a $0.4 \times$ objective and exposure set to $17 \mathrm{~s}$. Achieved voxel size during overall scan was $11.7 \mu \mathrm{m}$. All three scans had binning set to 2 times as well as variable exposure time set to 2 at the thickest part of the sample. Prior to each scan a warmup scan was conducted that lasted $25 \mathrm{~min}$. Acquired images were imported into Dragonfly PRO (version 2020.2) software platform for interactive segmentation and $3 \mathrm{D}$ visualization. Final image plates were assembled using Adobe Photoshop CC (version 2019-20.0.5).

Body length of the examined specimen was measured from the clypeus to apex of elytra, body width at the widest part of the body, pronotal length at midline, and pronotal width at the widest part. Morphological terminology follows Jin et al. (2013b) and Johnston and Gimmel (2020). The holotype is deposited in the collection of the Department of Palaeontology of the National Museum, Prague, Czech Republic (NMPC). The ZooBank LSID number for this publication is urn:lsid:zoobank.org:pub:F55CA75B-AF7C-4F1FBD65-DCBEAAC75410 (12 March 2021).

\section{Systematic paleontology}

Order Coleoptera Linnaeus, 1758

Suborder Polyphaga Emery, 1886

Series Elateriformia Crowson, 1960

Superfamily Dascilloidea Guérin-Méneville, 1843

Family Dascillidae Guérin-Méneville, 1843

Subfamily Karumiinae Escalera, 1913

Genus Baltodascillus gen. nov.

Type species Baltodascillus serraticornis sp. nov., here designated

urn:lsid:zoobank.org:act:A2B037D4-8951-4BE28263-4891CCD03E3B; Figs. 1-4, Video supplements $1-4$ 


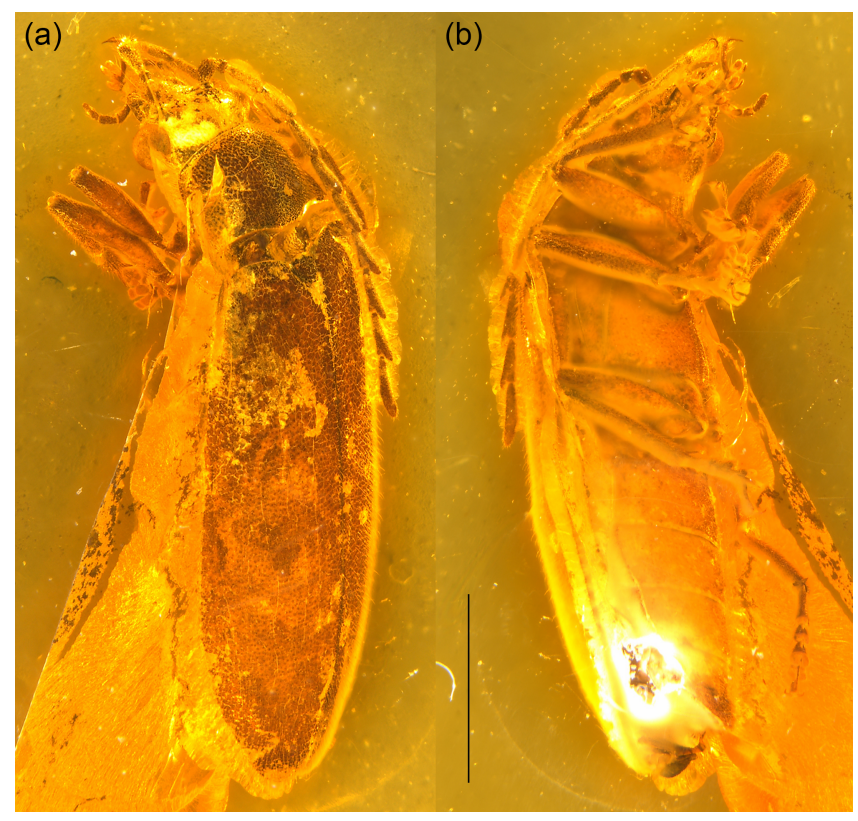

Figure 1. Baltodascillus serraticornis gen. et sp. nov., holotype: (a) habitus, dorso-frontal view; (b) habitus, ventro-lateral view. Scale bar $=2.0 \mathrm{~mm}$.

\section{Etymology}

Derived from the words "Baltic" (referring to Baltic amber) and "Dascillus" (a genus name in Dascillidae). Gender: masculine.

\section{Diagnosis}

Baltodascillus gen. nov. can be recognized among other genera of Dascillidae by the reduced mandibles (Figs. 2a, 3d). Additionally, the following combination of characters serves to distinguish it from all other genera: strongly serrate antennae, a fusiform terminal maxillary palpomere, large eyes, pronotum widest posteriorly and with a strongly developed lateral carina, lack of a developed prosternal process, complete elytra, confused elytral punctation, a weakly developed elytral epipleuron, and abdomen with five ventrites (Figs. 1$4)$.

\section{Description}

Body (Fig. 1) narrowly elongate. Eyes large, strongly protuberant. Frontoclypeal suture distinctly impressed. Labrum wider than long, distinctly sclerotized, anteriorly slightly concave. Antenna (Figs. 1-3) serrate, almost reaching middle of elytra; antennomeres 3-10 with prominent, acute serrations; terminal antennomere simple, elongate, apically rounded. Mandible (Figs. 2a, 3d) considerably reduced, very short, subtriangular, without teeth, apically narrowly rounded. Maxillary and labial palpi (Figs. 2c, d; 3; 4a, b) each with terminal palpomere fusiform, apically flattened and narrowly rounded.

Pronotum (Figs. 2b, c; 3a, d) transverse, widest near posterior angles; sides weakly arcuate; lateral carinae distinct, complete; posterior angles weakly acute; posterior edge weakly crenulate. Hypomeron with postcoxal process obtuse. Prosternal process (Figs. 3b; 4b, c) not developed, forming short right-angled denticle. Elytra (Figs. 1a; 2a, b) elongate, lateral edges more or less straight, widest at apical third, then gradually narrowed towards apex; elytral surface without costae or striae; elytral punctures irregular, only partially in weakly defined rows; elytral epipleuron narrow and oblique behind humeral area. Leg (Figs. 1b; 2d; 4a, b) with tibia about as long as femur in fore- and midlegs, and slightly longer than femur in hind legs; tibial spurs paired, approximately equal in length, serrate. Tarsomeres (Figs. 2e, f; 4f, g) 1-4 each with membranous ventral lobe; lobes gradually larger from tarsomere 1 to tarsomere 4 , those on tarsomeres 2-4 strongly bilobed.

Abdomen (Figs. 1b; 4d, e) with five ventrites; ventrites 1-4 gradually shorter towards apex; ventrite 1 without delimited hind coxal cavities, and with intercoxal process indistinct; ventrite 5 slightly longer than 4 , triangular, narrowly rounded apically.

\section{Composition and distribution}

Baltodascillus gen. nov. is a monotypic genus and is known exclusively from Eocene Baltic amber.

\section{Baltodascillus serraticornis sp. nov.}

urn:1sid:zoobank.org:act:1839A0BD-37DB-4F9A-ABB912C8300682E1; Figs. 1-4, Video supplements 1-4.

\section{Type material}

Holotype, adult male, NM-T 3470 (NMPC, ex coll. R. Kundrata, Olomouc, No. BAL0012, ex coll. J. Damzen, Lithuania, No. 8751). A complete beetle is included in an elongate, transparent, yellow amber piece with dimensions of $32 \times 15 \times 4 \mathrm{~mm}$, weighing approximately $1.7 \mathrm{~g}$, without any syninclusions.

\section{Type stratum and age}

Mid-late Eocene, 48-34 Ma (Seyfullah et al., 2018; Bukejs et al., 2019; Kasiński et al., 2020; Sadowski et al., 2017, 2020).

\section{Type locality}

Baltic Sea coast, Yantarny mine, Sambian (Samland) Peninsula, Kaliningrad Oblast, Russia. 


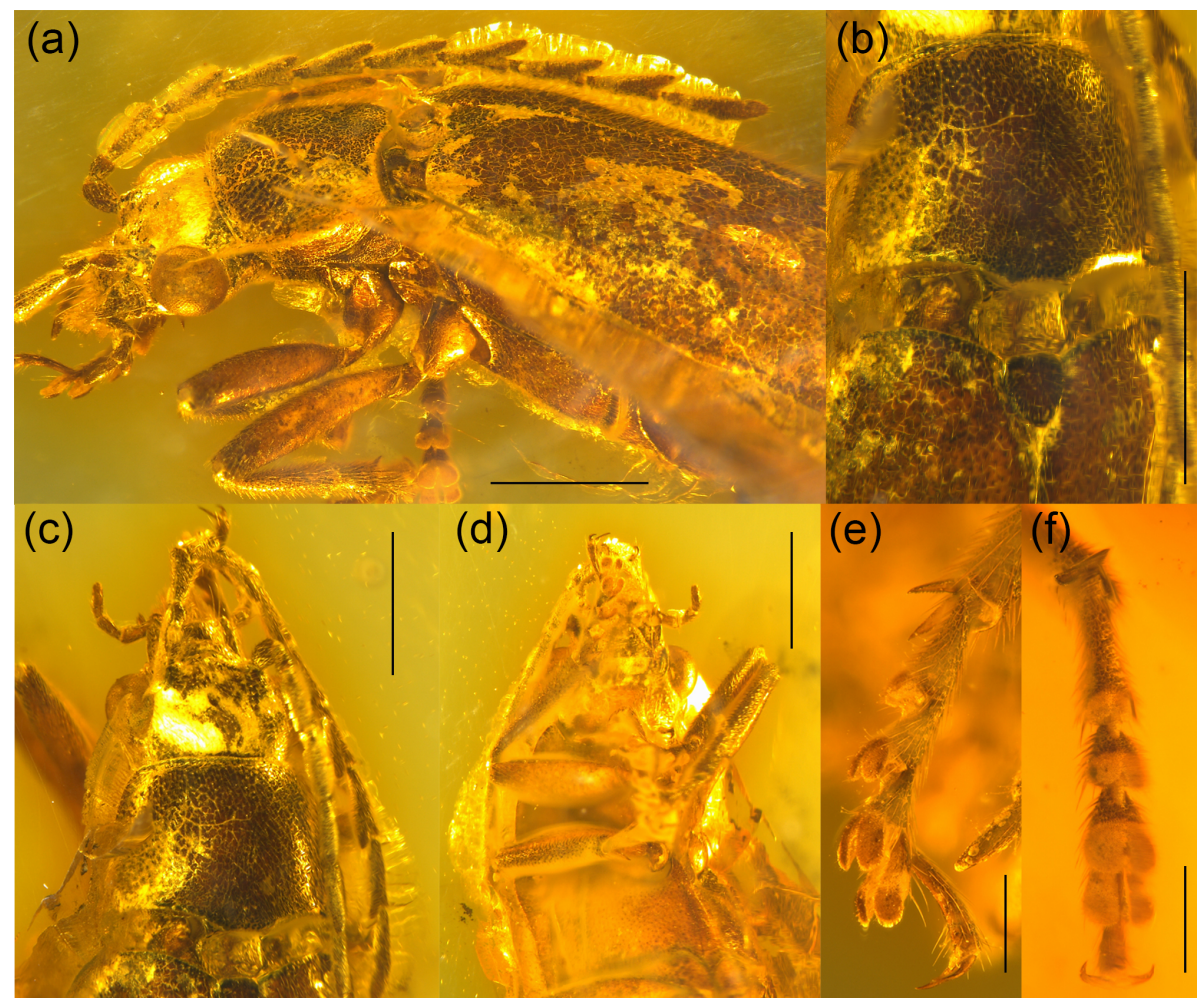

Figure 2. Baltodascillus serraticornis gen. et sp. nov., holotype: (a) habitus, lateral view; (b) pronotum and scutellar shield, dorsal view; (c) head and pronotum, dorsal view; (d) head and thorax, ventral view; (e) tarsus, ventro-lateral view; (f) tarsus, ventral view. Scale bars = $1.0 \mathrm{~mm}(\mathbf{a}-\mathbf{d}), 0.3 \mathrm{~mm}(\mathbf{e}, \mathbf{f})$.

\section{Etymology}

The specific epithet "serraticornis" is a Latin adjective referring to the shape of the antennae.

\section{Diagnosis}

As for the genus (vide supra).

\section{Description}

Adult male. Body (Fig. 1) about $7.5 \mathrm{~mm}$ long and $2.5 \mathrm{~mm}$ wide, narrowly elongate, about 3 times as long as wide, weakly convex; dorsally moderately densely setose.

Head (Figs. 2a, c, d; 3; 4a, b) $1.5 \mathrm{~mm}$ wide, subquadrate, 0.8 times as wide as pronotum width. Eyes large, strongly protuberant. Frontoclypeal suture distinctly impressed, more or less straight; clypeus short and strongly transverse. Labrum wider than long, distinctly sclerotized, anteriorly slightly concave, with discal setae longer than length of exposed portion of labrum. Antenna (Figs. 1-3) serrate, almost reaching middle of elytra; scape slightly longer than pedicel; pedicel slightly longer than wide; antennomeres 3-10 elongate, with prominent, acute serrations; terminal antennomere simple, slightly curved, elongate, about 1.4 times as long as antennomere $\mathrm{X}$, apically rounded. Mandible
(Figs. 2a, 3d) considerably reduced, very short, subtriangular, without teeth, apically narrowly rounded. Maxillary palpus (Figs. 2c, d; 3; 4a, b) moderately long; penultimate palpomere elongate, shorter than preceding one, about twice as long as wide; terminal palpomere fusiform, slightly longer than penultimate palpomere, about 2.5 times as long as wide, apically flattened and narrowly rounded. Labial palpus distinctly shorter than maxillary palpus, with terminal palpomere fusiform.

Pronotum (Figs. 2b, c; 3a, d) transverse, about 1.7 times wider than long (1.9 mm wide, $1.1 \mathrm{~mm}$ long), widest just anterior to posterior angles; sides weakly arcuate; lateral carinae distinct, complete, slightly explanate; anterior angles obtuse, not projecting, posterior angles weakly acute; posterior edge tri-emarginate and weakly crenulate along entire length; disk slightly convex, with rather smooth surface. Hypomeron with postcoxal process obtuse. Prosternum (Figs. 3b; 4b, c) in front of coxa about as long as procoxal diameter; prosternal process not developed, forming short right-angled denticle. Pronotosternal suture complete. Scutellar shield (Figs. 1a; 2b; 3a) slightly longer than wide, weakly rounded anteriorly, narrowly rounded posteriorly. Elytra (Figs. 1a; 2a, b) together about 2.4 times as long as wide (5.9 mm long, $2.5 \mathrm{~mm}$ wide) and 5.0 times as long as pronotum; weakly convex, more or less straight, widest at apical third, then gradually narrowed 


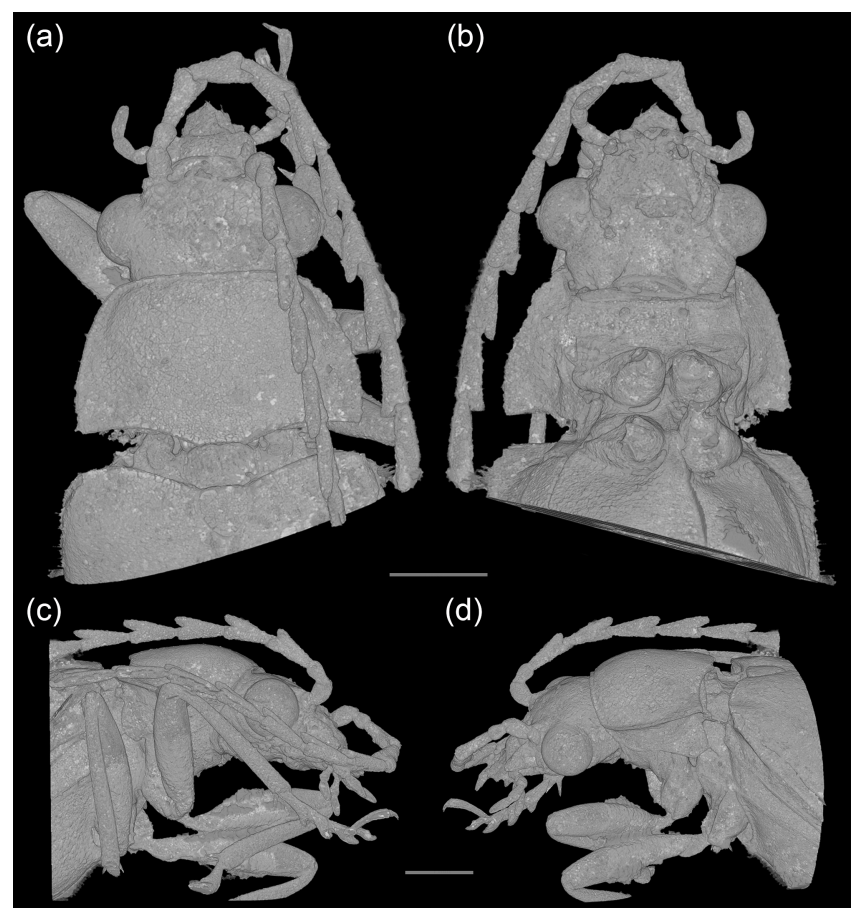

Figure 3. Baltodascillus serraticornis gen. et sp. nov., holotype, Xray micro-CT renderings: (a) head and thorax, dorsal view; (b) head and thorax, ventral view; (c) head and thorax, right lateral view; (d) head and thorax, left lateral view. Scale bars $=1.0 \mathrm{~mm}$.

towards apex; elytral surface without costae or striae; elytral punctures irregular, only partially in weakly defined rows; elytral intervals flat; elytral epipleuron narrow and oblique behind humeral area. Mesoventrite (Figs. 3b; 4b, c) with anterior edge medially on the same plane as metaventrite, forming short triangular projection laterally bordered by procoxal rests. Mesocoxal cavities separated by narrow mesoventral process. Metaventrite wider than long, moderately convex. Metacoxae contiguous, extending laterally to level of elytral epipleuron; metacoxal plate well developed mesally. Hind wing fully developed. Leg (Figs. 1b; 2d; 4a, b) slender, femur robust, elongate; tibia about as long as femur in foreand midlegs, and slightly longer than femur in hind legs; each tibia with pair of distinctly serrate spurs approximately equal in length. Tarsomere 1 distinctly longer than tarsomere 2 , tarsomeres 2-4 gradually shorter towards apex, each of tarsomeres 1-4 with membranous ventral lobe; lobes gradually larger from tarsomere 1 to tarsomere 4, those on tarsomeres 2-4 strongly bilobed (Figs. 2e, f; 4f, g); claws simple, moderately curved; empodium absent.

Abdomen (Figs. 1b; 4d, e) with five ventrites, with surface moderately densely covered by fine punctures; ventrites $1-4$ gradually shorter towards apex; ventrite 1 without delimited hind coxal cavities, and with intercoxal process indistinct; ventrite 5 slightly longer than 4 , triangular, narrowly rounded apically, apical half of ventrite in slightly different plane from basal half. Tergite $\mathrm{X}$ triangular, apically narrowly rounded. Aedeagus with only parameres visible but not median lobes.

\section{Remark}

We conclude that the examined specimen is a male based on the shape of the body, serrate antennae, a long, narrowly rounded abdominal ventrite 5 , and aedeagal structure (parameres) detected in X-ray micro-CT imaging.

\section{Discussion}

In order to understand the placement of the newly discovered fossil genus within Dascillidae, it is important to acknowledge the currently problematic situation with the subfamilial classification of the group. As currently delimited, Dascillidae contain two vaguely defined subfamilies with a divergent taxonomic history (Lawrence and Newton, 1995; Lawrence, 2016). Free-living and non-modified Dascillinae occur in non-arid areas of western North America, the Greater Antilles, Palearctic and Oriental regions, western Africa, and Australia. Karumiinae, which contain morphologically modified lineages of which at least some are associated with subterranean termites, are mostly distributed in arid and semiarid regions of western North America, northern Africa, central Asia and southern South America (Lawrence and Newton, 1995; Jin et al., 2013b; Lawrence, 2016). The latter group had long been treated as a separate family, Karumiidae, associated with the families of former Cantharoidea (i.e., roughly the soft-bodied Elateroidea) and originally included only the morphologically highly modified groups near Karumia Escalera, 1913 with an apparently soft cuticle, variously reduced elytra and unknown females (Crowson, 1955; Arnett, 1964; Paulus, 1972). Crowson (1971) first associated Karumiidae with Dascillidae based on a number of morphological characters, although he still kept the family status for both groups. He also transferred the genera Anorus LeConte, 1859, Pleolobus Philippi and Philippi, 1864 (Fig. 5), Genecerus Walker, 1871 and Emmita Escalera, 1914 from Dascillidae to Karumiidae and provided updated diagnoses for both groups. Based on his key, the Karumiidae contained taxa with a simple galea, the ligula with two short lobes, the ventral tarsal lobes absent or not basally articulated, the corpotentorium very broad, the male antenna pectinate or flabellate, and females wingless (apparently referring to known females of Anorus sp. with shortened elytra and reduced hind wings). However, Crowson's characters for separating the two subfamilies have been largely problematic since they do not apply to all included genera, and especially certain intermediate groups like Genecerus violate the diagnosis of Karumiinae (Lawrence and Newton, 1995; Lawrence, 2016). For example, both subfamilies share a very broad corpotentorium, the ventral lobes on tarsomeres of Genecerus and Anorus are similar to those in Das- 


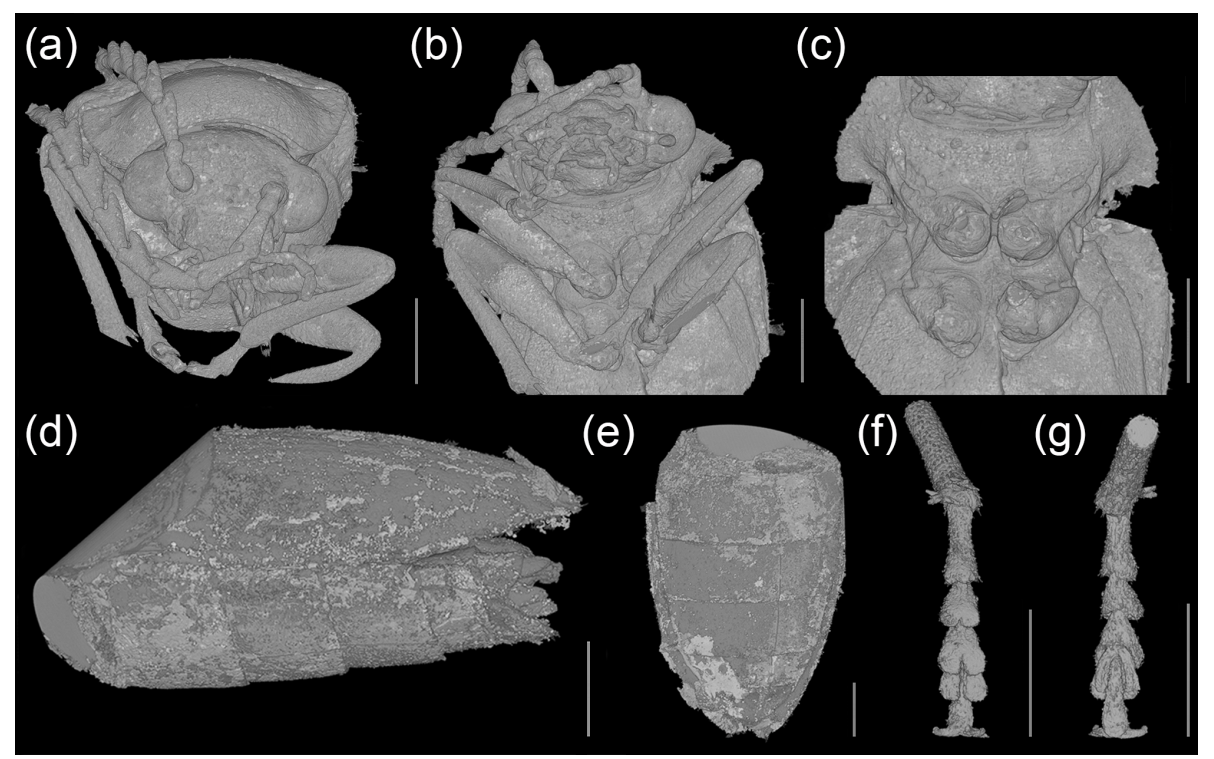

Figure 4. Baltodascillus serraticornis gen. et sp. nov., holotype, X-ray micro-CT renderings: (a) head, frontal view; (b) head and thorax, fronto-ventral view; (c) pro- and mesothorax, ventral view; (d) abdomen (ventrites 2-5), lateral view; (e) abdomen (ventrites 2-5), ventral view; (f) tarsus, ventral view; (g) tarsus, dorsal view. Scale bars $=1.0 \mathrm{~mm}$.

cillinae, at least females of Genecerus have well-developed hind wings (Lawrence, 2016), and serrate to pectinate antennae are known only in Emmita and Genecerus but not in any other karumiine genus. Additionally, Grebennikov and Scholtz (2003) concluded that the larval morphology of Pleolobus is highly similar to that of Dascillinae, with the primary difference being that the latter possess molar ridges on the mandible. Unfortunately, the relationships among the dascillid genera have never been tested using a focused molecular approach. The only available molecular phylogenetic analyses, although either preliminary or focused on broader issues, have nonetheless called into question the current subfamilial classification (Kundrata et al., 2017; Johnston and Gimmel, 2020).

Representatives of Dascillidae display a graded series of morphological modifications connected with possible neoteny and soft-bodiedness, similar to the situation in various Elateroidea (Cicero, 1988; Kundrata and Bocak, 2019). In Dascillidae, the modifications represent a continuum from the well-sclerotized groups with adults of both sexes fully developed (although at least some females might have slightly less developed hind wings than their counterparts) (traditional Dascillinae), through more or less soft-bodied groups with males with complete elytra and females with variously shortened elytra and reduced hind wings (Anorus spp., Pleolobus, probably also Emmita) (Fig. 5) to the soft-bodied forms with males with greatly shortened elytra and females unknown but probably even more dramatically modified, termitiform (most Karumia) (Paulus, 1972; Solervicens, 1991; Ivie and Barclay, 2011; Johnston and Gimmel, 2020). Such modifications also affect the morphology of the thorax, such that the hard-bodied groups have a well-developed, spinelike prosternal process, whereas the soft-bodied forms have the prosternal process dramatically reduced to form a short triangle-shaped denticle. It is probable that the modifications of morphology connected with the independent evolution of soft-bodiedness have influenced the formal classification of Dascillidae, similar to many cases in the Elateroidea (Kundrata and Bocak, 2019). This hypothesis, however, needs to be tested using a well-sampled molecular phylogenetic analysis.

Under the current state of knowledge, we tentatively place the newly described Baltodascillus gen. nov. in Karumiinae based on the large eyes, serrate antennae, and lack of a spine-like prosternal process. This fossil genus is morphologically similar to the New World genera Anorus and Pleolobus (Fig. 5) or the African/Middle Eastern genus Genecerus but differs from these in the strongly serrate (but not pectinate) antennae, crenulate hind margin of the pronotum, and confused elytral punctation. It differs from all known Dascillidae by the highly reduced mandibles which do not overlap and are apparently non-functional. Given the unusual nature of this character, further specimens of this genus will be critical in determining whether this is a stable character or the result of a single teratological specimen. This is the first representative of the Dascillidae formally described from Baltic amber and also the first described fossil member of the subfamily Karumiinae since Semenoviola obliquotruncata Martynov, 1925, originally described in that group, was determined to be a dermapteran (Bolívar y Pieltain, 1926). Also, Baltodascillus gen. nov. is the first karumiine known from Europe and, therefore, sheds light not only on the paleodi- 


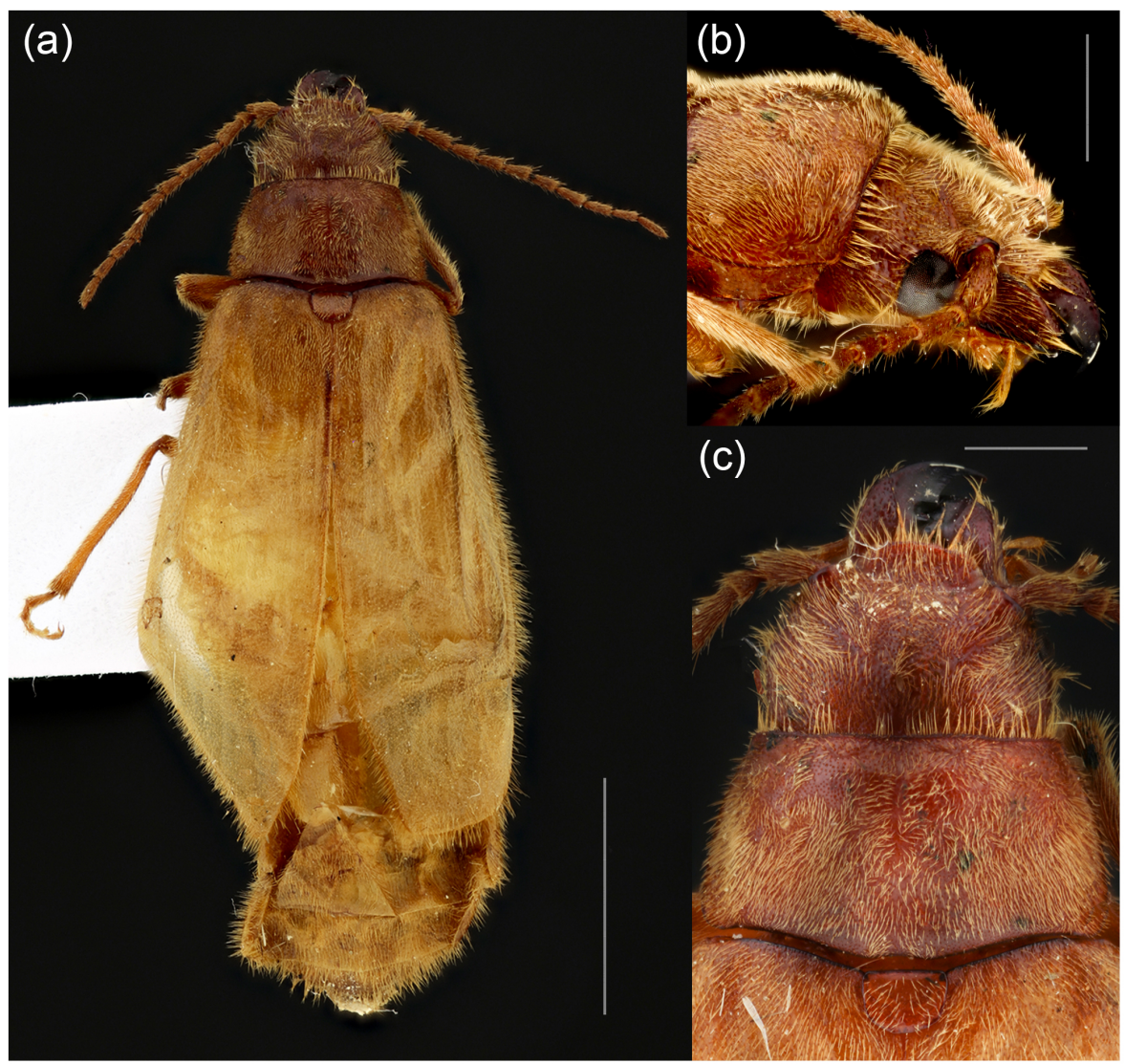

Figure 5. Pleolobus fuscescens Philippi et Philippi, 1864, female from Chile: (a) habitus, dorsal view; (b) head, lateral view; (c) head, pronotum and scutellar shield, dorsal view. Scale bars $=4.0 \mathrm{~mm}(\mathbf{a}), 1.0 \mathrm{~mm}(\mathbf{b}, \mathbf{c})$. All images by Jorge Jensen.

versity and systematics of the group but also on its biogeography.

Data availability. The holotype of Baltodascillus serraticornis gen. et sp. nov. is deposited in the collection of the Department of Palaeontology of the NMPC. Volume renderings of X-ray microtomography of habitus, head/prothorax, hind tarsus, and abdomen are available as Video supplements $1-4$, respectively.

Video supplement. X-ray micro-CT volume renderings of the habitus, head/pterothorax, hind tarsus, and abdomen of Baltodascillus serraticornis gen. et $\mathrm{sp}$. nov. are available at https://doi.org/10.5446/52211 (Video supplement 1, Kundrata et al., 2021a), https://doi.org/10.5446/52212 (Video supplement 2, Kundrata et al., 2021b), https://doi.org/10.5446/52213 (Video supplement 3, Kundrata et al., 2021c), https://doi.org/10.5446/52214 (Video supplement 4, Kundrata et al., 2021d).

Author contributions. RK conceived and designed the study. MLG and RK carried out the morphological investigation. $\mathrm{AB}$ conducted the micro-CT scanning. SMB prepared microphotographs.
GP and RK prepared figure plates. RK and MLG wrote the initial manuscript with help of GP, AB, and SMB. All authors performed the literature search, discussed the results, and edited, reviewed, and approved the manuscript.

Competing interests. The authors declare that they have no conflict of interests.

Acknowledgements. We are grateful to Kristaps Kairišs (Daugavpils University, Daugavpils, Latvia) for the assistance in Xray micro-computed tomography and to Jonas Damzen (Vilnius, Lithuania), Jiří Kvaček and Jiřina Dašková (NMPC) for their help during our research. Jorge Jensen (Santiago de Chile, Chile) is acknowledged for his photographs of the female Pleolobus fuscescens.

Financial support. Matthew L. Gimmel was funded in part by the Schlinger Foundation and generous donations from John Carson and Tom Dimock. 
Review statement. This paper was edited by Florian Witzmann and reviewed by Shuhei Yamamoto and one anonymous referee.

\section{References}

Arnett Jr., R. H.: Notes on Karumiidae (Coleoptera), Coleopts. Bull., 18, 65-68, 1964.

Bolívar y Pieltain, C.: Sobre una nueva familia de Coléoptères (Karumidae o Zarudniolidae), Eos, 2, 191-204, 1926.

Bukejs, A., Alekseev, V. I., and Pollock, D. A.: Waidelotinae, a new subfamily of Pyrochroidae (Coleoptera: Tenebrionoidea) from Baltic amber of the Sambian peninsula and the interpretation of Sambian amber stratigraphy, age and location, Zootaxa, 4664, 261-273, https://doi.org/10.11646/zootaxa.4664.2.8, 2019.

Carter, H. J.: Australian Coleoptera. Notes and new species, No. IX, Proc. Linn. Soc. N. S. W., 60, 179-193, 1935.

Cicero, J. M.: Ontophylogenetics of cantharoid larviforms (Coleoptera: Cantharoidea), Coleopts. Bull., 42, 105-151, 1988.

Crowson, R. A.: The natural classification of the families of Coleoptera, Nathaniel Lloyd \& Co., London, UK, 187 pp., 1955.

Crowson, R. A.: Observations on the superfamily Dascilloidea (Coleoptera: Polyphaga), with the inclusion of Karumiidae and Rhipiceridae, Zool. J. Linn. Soc.-Lond., 50, 11-19, https://doi.org/10.1111/j.1096-3642.1971.tb00749.x, 1971.

de la Escalera, M. M.: Dos nuevas tribus de Drílidos, Bol. Soc. Esp. Hist. Nat., 13, 319-321, 1913.

de la Escalera, M. M.: Los Coléoptères de Marruecos, Trab. Mus. Ci. Nat., Madrid, Ser. Zool., 11, 1-553, 1914.

Dunstan, B.: Mesozoic insects of Queensland, Part 1. Introduction and Coleoptera, Geol. Sur. Qld. Publ., 273, 1-74, 1923.

Fang, Y., Yan, Y., and Jin, Z.: Description of a new species of Dascillus Latreille from Henan, China (Coleoptera: Dascillidae), Zootaxa, 4732, 341-345, https://doi.org/10.11646/zootaxa.4732.2.11, 2020.

Grebennikov, V. V. and Scholtz, C. H.: Larvae and pupae of Dascillidae (Coleoptera): morphological study and discussion of their relationships to Scarabaeoidea and Eulichadidae, Insect Syst. Evol., 34, 29-39, https://doi.org/10.1163/187631203788964908, 2003.

Guérin-Méneville, F. E.: Note sur un groupe naturel ou une petite tribu de Coléoptères de la famille des malacodermes, Rev. Zool., 6, 193-194, 1843.

Helm, O.: Mittheilungen über Bernstein, XIII. Über die Insecten des Bernsteins, Schrift. Naturforsch. Gesellsch. Danzig, 6, 267-277, 1886.

Helm, O.: Beiträge zur Kenntniss der Insecten des Bernsteins, Schrift. Naturforsch. Gesellsch. Danzig, 9, 220-231, 1896.

Hope, F. W.: Observations on the fossil insects of Aix in Provence, with descriptions and figures of three species, T. Roy. Ent. Soc. London, 4, 250-255, 1847.

Ivie, M. A. and Barclay, M. V. L.: The familial placement and specific membership of Escalerina Bolívar y Pieltain and Paulusiella Mandl, with new synonymies (Coleoptera: Elateridae, Dascillidae, Drilidae), Coleopts. Bull., 65, 167-172, 2011.

Jin, Z., Ślipiński, A., and Pang, H.: A revision of the genus Notodascillus Carter (Coleoptera: Dascillidae), Zootaxa, 3613, 245-256, https://doi.org/10.11646/zootaxa.3613.3.3, 2013a.
Jin, Z., Ślipiński, A., and Pang, H.: Genera of Dascillinae (Coleoptera: Dascillidae) with a review of the Asian species of Dascillus Latreille, Petalon Schonherr and Sinocaulus Fairmaire, Ann. Zool., 63, 551-652, https://doi.org/10.3161/000345413X676786, 2013b.

Jin, Z., Ślipiński, A., Pang, H., and Ren, D.: A new Mesozoic species of soft-bodied Plant beetle (Coleoptera: Dascillidae) from the Early Cretaceous of Inner Mongolia, China with a review of fossil Dascillidae, Ann. Zool., 63, 501-509, https://doi.org/10.3161/000345413X672492, 2013c.

Jin, Z., Ślipiński, A., and Wang, W.: Description of a new species of Sinocaulus Fairmaire from China (Coleoptera: Dascillidae), Zootaxa, 3974, 582-588, https://doi.org/10.11646/zootaxa.3974.4.9, 2015.

Jin, Z., Xie, G., and Yang, Q.: Description of a new species of Dascillus Latreille from Sichuan, China (Coleoptera: Dascillidae), Zootaxa, 4200, 321-323, https://doi.org/10.11646/zootaxa.4200.2.5, 2016.

Jin, Z., Xie, G., and Zhu, Y.: Description of a new species of Dascillus Latreille from China (Coleoptera: Dascillidae), Ann. Zool., 67, 87-90, https://doi.org/10.3161/00034541ANZ2017.67.1.010, 2017.

Johnston, M. A. and Gimmel, M. L.: Review of North American Dascillidae (Coleoptera: Dascilloidea), with descriptions of dramatic female wing reduction, Coleopts. Bull., 74, 731-757, https://doi.org/10.1649/0010-065X-74.4.731, 2020.

Kasiński, J. R., Kramarska, R., Słodkowska, B., Sivkov, V., and Piwocki, M.: Paleocene and Eocene deposits on the eastern margin of the Gulf of Gdańsk (Yantarny P-1 bore hole, Kaliningrad region, Russia), Geol. Q., 64, 29-53, https://doi.org/10.7306/gq.1513, 2020.

Kirejtshuk, A. G. and Azar, D.: Current knowledge of Coleoptera (Insecta) from the Lower Cretaceous Lebanese amber and taxonomical notes for some Mesozoic groups, Terr. Arthropod Rev., 6, 103-134, 2013.

Klebs, R.: Über Bernsteineinschlüsse in allgemeinen und die Coleopteren meiner Bernsteinsammlung, Schrift. Physik.Ökonom. Gesellsch. Königsberg, 51, 217-242, 1910.

Kundrata, R. and Bocak, L.: Molecular phylogeny reveals the gradual evolutionary transition to soft-bodiedness in click-beetles and identifies Sub-Saharan Africa as a cradle of diversity for Drilini (Coleoptera: Elateridae), Zool. J. Linn. Soc.-Lond., 187, 413452, https://doi.org/10.1093/zoolinnean/zlz033, 2019.

Kundrata, R., Jäch, M. A., and Bocak, L.: Molecular phylogeny of the Byrrhoidea-Buprestoidea complex (Coleoptera: Elateriformia), Zool. Scr., 45, 150-164, https://doi.org/10.1111/zsc.12196, 2017.

Kundrata, R., Gimmel, M. L., Packova, G., Bukejs, A., and Blank, S. M.: Baltodascillus serraticornis, holotype, X-ray micro-CT volume rendering of the habitus, TIB AV-Portal, available at: https://doi.org/10.5446/52211, 2021a.

Kundrata, R., Gimmel, M. L., Packova, G., Bukejs, A., and Blank, S. M.: Baltodascillus serraticornis, holotype, X-ray micro-CT volume rendering of the head/pterothorax, TIB AV-Portal, available at: https://doi.org/10.5446/52212, 2021b.

Kundrata, R., Gimmel, M. L., Packova, G., Bukejs, A., and Blank, S. M.: Baltodascillus serraticornis, holotype, X-ray micro-CT volume rendering of the hind tarsus, TIB AV-Portal, available at: https://doi.org/10.5446/52213, 2021c. 
Kundrata, R., Gimmel, M. L., Packova, G., Bukejs, A., and Blank, S. M.: Baltodascillus serraticornis, holotype, X-ray micro-CT volume rendering of the abdomen, TIB AV-Portal, available at: https://doi.org/10.5446/52214, 2021d.

Larsson, S. G.: Baltic amber - A palaeobiological study, Entomonograph, 1, 1-192, 1978.

Latreille, P. A.: Précis des caractères génériques des insectes, disposés dans un ordre naturel, Prévôt, Bourdeaux, Brive, Paris, France, 201 pp., 1797.

Lawrence, J. F.: Dascillidae Guérin-Méneville, 1843, in: Handbook of Zoology, Coleoptera, Beetles, Morphology and Systematics (Archostemata, Adephaga, Myxophaga, Polyphaga partim), edn. 2, edited by: Beutel, R. G. and Leschen, R. A. B., Walter de Gruyter, Berlin/Boston, Germany/USA, 531-537, 2016.

Lawrence, J. F. and Newton, A. F.: Families and subfamilies of Coleoptera (with selected genera, notes, references and data on familygroup names), in: Biology, phylogeny, and classification of Coleoptera, edited by: Lawrence, J. F., Pakaluk, J. F., and Ślipiński, S. A., Museum i Instytut Zoologii PAN, Warzawa, Poland, 779-1092, 1995.

LeConte, J. L.: Catalogue of the Coleoptera of Fort Tejon, California, P. Acad. Nat. Sci. Phila., 11, 69-90, 1859.

Lewis, S. E.: A new species of fossil beetle (Coleoptera: Dascillidae) from the Latah Formation (Miocene) of Eastern Washington, Ann. Entomol. Soc. Am., 66, 697-697, 1973.

Li, F., Ślipiński, A., and Jin, Z.: Description of a new species of Dascillus Latreille from Yunnan, China (Coleoptera: Dascillidae), Zootaxa, 4341, 433-436, https://doi.org/10.11646/zootaxa.4341.3.10, 2017.

Martynov, A. V.: On a new interesting fossil beetle from the Jurassic beds in North Turkestan, Rus. Ent. Obozr., 19, 73-78, 1925.

Martynov. A. V.: K poznaniyu iskopaemykh nasekomykh Yurskikh slantsev Turkestana, 5. O nekotorykh formakh zhukov (Coleoptera), Ezhegodnik Russkogo Paleontologicheskogo Obshestva, 5, 1-39, 1926.

Paulus, H. F.: Die systematische und phylogenetische Stellung der Karumiidae, mit einer Beschreibung von Escalerina serraticornis n. sp. aus S-Persien (Ins.: Coleoptera: Cantharoidea), Senckenberg Biol., 53, 37-54, 1972.

Paykull, G.: Fauna Svecica. Insecta. Tomus. II, J. F. Edman, Upsaliae [Uppsala], Sweden, 234 pp., 1799.

Philippi, R. A. and Philippi, F.: Beschreibung einiger neuen Chilenischen Käfer, Stett. Entomol. Z., 25, 266-284, 1864.

Sadowski, E.-M., Seyfullah, L. J., Schmidt, A. R., and Kunzmann, L.: Conifers of the "Baltic amber forest" and their palaeoecological significance, Stapfia, 106, 1-73, 2017.
Sadowski, E.-M., Schmidt, A. R., and Denk, T.: Staminate inflorescences with in situ pollen from Eocene Baltic amber reveal high diversity in Fagaceae (oak family), Willdenowia, 50, 405-517, https://doi.org/10.3372/wi.50.50303, 2020.

Seyfullah, L. J., Beimforde, C., Dal Corso, J., Perrichot, V., Rikkinen, J., and Schmidt, A. R.: Production and preservation of resins - past and present, Biol. Rev., 93, 1684-1714, https://doi.org/10.1111/brv.12414, 2018.

Solervicens, J.: Descripcion de la hembra de Pleolobus fuscescens Philippi y Philippi (Coleoptera, Karumiidae) y observaciones sobre esta especie, Acta Ent. Chil., 16, 119-124, 1991.

Spahr, U.: Systematischer Katalog der Bernstein- und Kopal-Käfer (Coleoptera), Stuttg. Beitr. Naturkd. B, 80, 1-107, 1981.

Terzani, F., Ceccolini, F., Hájek, J., and Cianferoni, F.: Taxonomic review of the genus Dascillus Latreille, 1797 in the western Palaearctic (Coleoptera: Dascillidae), Zootaxa, 4282, 255-268, https://doi.org/10.11646/zootaxa.4282.2.2, 2017.

Walker, F.: List of Coleoptera collected by Lord, J. K., ESQ, in: Egypt, Arabia and near the African shore of the Red Sea, with characters of the undescribed species, E. W. Janson, London, UK, 1871.

Wang, J., Li, S., and Jin, Z.: Two new species of the genus Dascillus Latreille from Yunnan Province, China (Coleoptera: Dascillidae), Orient. Insects, 54, 106-113, https://doi.org/10.1080/00305316.2019.1588803, 2020a.

Wang, J., Zhang, N., Li, S., and Jin, Z.: Description of two new species of Dascillus Latreille from southwest China (Coleoptera: Dascillidae), Orient. Insects, 54, 556-563, https://doi.org/10.1080/00305316.2019.1697387, 2020b.

Wickham, H. F.: Fossil Coleoptera from Florissant, with descriptions of several new species, B. Am. Mus. Nat. Hist., 30, 53-69, 1911.

Wickham, H. F.: New Miocene Coleoptera from Florissant, Bull. Mus. Comp. Zool., 58, 423-494, 1914.

Yan, V. B., Wang, B., and Zhang, H.: Two new genera of Lasiosynidae (Insecta, Coleoptera) from the Lower Cretaceous of Russia and Mongolia, and principal trends of the morphological evolution of the family, Paleontol. J., 48, 500-511, https://doi.org/10.1134/S0031030114050128, 2014.

Zhang, J.: Fossil insects from Shanwang, Shandong, China, Shandong Science and Technology Publishing House, Jinan, China, 1989.

Zhang, J., Sun, B., and Zhang, X.: Miocene insects and spiders from Shanwang, Shandong, Science Press, Beijing, China, 1994. 